\title{
Transforming a Course to Blended Learning for Student Engagement
}

\author{
Charles E. Downing, ${ }^{1}$ Julia Spears, ${ }^{2}$ and Michaela Holtz ${ }^{2}$ \\ ${ }^{1}$ Operations Management and Information Systems Department, College of Business, Northern Illinois University, \\ DeKalb, IL 60115, USA \\ ${ }^{2}$ Office of Student Engagement \& Experiential Learning, Northern Illinois University, DeKalb, IL 60115, USA
}

Correspondence should be addressed to Charles E. Downing; cdowning@niu.edu

Received 2 September 2014; Accepted 19 November 2014; Published 9 December 2014

Academic Editor: Cathy H. Qi

Copyright (C) 2014 Charles E. Downing et al. This is an open access article distributed under the Creative Commons Attribution License, which permits unrestricted use, distribution, and reproduction in any medium, provided the original work is properly cited.

\begin{abstract}
The rising costs of higher education, along with the learning styles and needs of modern students, are changing the instructional landscape. Students of today do less and less well in the "lecture only" format, and staffing this format with live faculty is extremely expensive. MOOCs and other technology-heavy options are low cost but quite impersonal. Blended instruction has promise, with the ultimate goal of cost-efficient student engagement. This paper reports on a major course transformation to achieve student engagement in a large, formerly lecture-only course. The resulting blended-learning course features clickers, web-based operationalization of students helping students, media-rich interactive online materials, event credit, and newly added studentproduced video tutorials. Results show that the addition of the student-produced video tutorials increased the student engagement in the course.
\end{abstract}

\section{Introduction}

A teenaged-daughter enjoyed watching old Saturday Night Live episodes on Netflix, so her father took her to The Second City comedy club in Chicago to see some budding SNL prospects. The evening cost over $\$ 150$, compared to an average of less than $\$ 1$ per SNL episode on Netflix. Why the difference? The cost of live performers, of course.

Instructional faculty is live performers in the classroom, and the rising costs of higher education are threatening their existence. One key to their survival is student engagement. The real time, multimodal digitally connected students of today do less and less well in the "lecture only" format [1], a format which has shown an upper limit of about $30 \%$ content retention regardless of lecturer [2]. If this format continues to be chosen Massively Open Online Courses (MOOCs) and other technology-assisted options could permanently remove the live performers.

This paper reports on a major course transformation, following the guidelines of University of North Texas' NextGen program. The resulting blended-learning course features clickers, web-based operationalization of students helping students, media-rich interactive online materials, event credit, and newly added student-produced video tutorials.

\section{Theoretical Grounding: The Goal of Student Engagement}

With the shifting landscape of higher education, many colleges and universities have turned to student engagement activities as a way to ensure deep learning occurs among students $[3,4]$. Universities want graduates equipped with skills and knowledge necessary for the 21st century career. Through campus-wide strategic planning initiatives that seek to adjust curricular and cocurricular programming to meet the needs of a changing student body, student engagement has emerged with force. According to a recent survey of employers, students' ability to problem-solve in diverse settings and to apply knowledge to issues in their fields are critical for career success [5]. These skills are at the core of the essential student learning outcomes that guide the work of the Liberal 
Education and America's Promise, a national initiative of the Association of American Colleges and Universities [6].

With the recent enthusiasm for MOOCs, many faculties are questioning the liberal education that now is accessible even to disadvantaged students. Newstok, in his recent article for AAC\&U's Liberal Education, proposed the term "close learning," a term that suggests the laborious, timeconsuming, and costly but irreplaceable proximity between teacher and student [7].

Can a video on YouTube, along with a textbook, be as valuable of an educational experience as attending a college class? What if the YouTube video features the most famous professor in the world giving the lecture? Many proponents of MOOCs might say "yes" [8]. The key lies in what happens in the college class. If the professor is lecturing without any interaction, then these proponents might be correct. However, if the college class as a whole is more of an engaging experience than just a lecture, then imitation or replacement, at a level of equal or greater quality of learning, will be much more difficult $[8,9]$. And of course the students will be the beneficiaries.

So what makes the classroom an engaging experience? Research suggests that it stems from a combination of rich instructor-student, student-student, and student-technology interactions. Rather than focusing on delivering content, Zull [10] explains that the instructor must facilitate learning, being the manager of the process that brings the students to the point where they believe that they learned by themselves. This is accomplished by highlighting nuances in content, clarifying difficult or unclear concepts, assigning group-based learning, directing students to appropriate, often technologybased, sources of learning, and holding students accountable for their involvement in all of these activities.

As "managers," instructors can help students immensely by providing and ensuring valuable student-student and student-technology interactions. Ambrose et al. [11] note that students often understand content better when it is presented by peers. Peer interaction at all stages of the classroom experience can help smooth over differences in background and knowledge-level without the instructor having to work individually with each student [12]. Metcalfe and Kornell [13] found that the timing of the delivery of content was crucial. Tallent-Runnels et al. [14] showed that students like to move at their own pace. Smith and Vela [15] showed that changing the environment helped students assimilate content. Both peers and technology have the ability to provide learning assistance without the time and space constraints of a normally scheduled class [16, 17], and when students find the process of organizing and participating in extra sessions or interactions relatively convenient, they are much more likely to participate [11]. The manner in which peers and/or technology provide assistance is often refreshingly different from the instructor, and this can enhance student learning. In fact, Roscoe and Chi [18] and Griffin et al. [19] found that explanations given in addition to those from the instructor increased student learning. And both Bereiter and Scardamalia [20] and Bjork [21] discovered that varying the material presentation and content explanation facilitated learners' active integration of the information. Finally, Mayer and Moreno [22] showed that content needed to be presented in manageable chunks to ensure that students do not get overwhelmed. Media rich interactive online technology can be divided into segments that students can complete on a 24/7 basis, at a pace and schedule that works for them [23].

Close learning still allows for engaging in meaningful conversations outside of the classroom, correspondence with faculty through email or the use of new technology. However, it is all in service of close learning and the payoff comes in the classroom, where students have the ability to interact and to think hard thoughts alongside other people [7]. Therefore, a blending of close learning with technology assistance and outside-of-class contacts is desirable [24].

\section{Multiple Pedagogies of Engaged Learning}

Instructors often observe students text messaging, use of social media, and in some cases sleeping in the back rows in the typical large lecture class which relies heavily on lecture and passive methods of learning. This fact is no surprise given the average attention span of college students being 15 to 20 minutes [25]. Additionally, a large variety of student cultural backgrounds, concerns, and needs are present in a single classroom [26]. Lecturing is an important instrument in each educator's toolbox, but it should not be the only tool. According to Wurdinger and Carlson [25], lectures should be used to help students understand theories. Students can then go out and test these theories against reality during and after the course, helping to prevent them from forgetting the information in the future.

During the college years, students experience fundamental shifts in the perception of self and others. They also experience a phase called "focused exploration" [25]. This is the time when they attempt to decide what they want to do with their lives and should be exposed to opportunities such as "studying abroad, service learning, cooperative learning, internships, and conducting observations outside of classroom" ([25], p. 2).

The recent shift in higher education has focused on the impact of engaged learning on students' success and persistence. A great deal of research and literature has been done suggesting that engaging students in purposeful educational activities had positive and statistically significant impact on both GPA and retention $[1,27]$.

Despite the amount of attention, there is no crystallized definition of engaged learning among educators or researchers [3]. Turner and Carriveau [1] tell us that "a cognitively engaged student is one who is making meaning by expanding upon the knowledge structures provided to them. There is also a socially engaged student who has developed relationships with faculty and peers." ([1], p. 15). Swaner [28] refers to four major dimensions of engaged learning that enrich, deepen, and intensify students' learning: the developmental dimension (fostering intellectual complexity), the holistic dimension (encompassing multiple domains in learningcognitive, personal, and social), the integrative dimension (integrating types, sources, and temporality of learning), and the contextual dimension (promoting independence and engagement in community). In order to encompass all four 
dimensions into engaged learning, pedagogies that foster intellectual complexity, involve multiple domains of self, integrate diverse learning processes and sources, and foster interdependence in and commitment to community are required [28]. Kuh identified a number of such highimpact practices that foster student engagement in learningcommon intellectual experiences, collaborative assignments and projects, first-year seminars and experiences, learning communities, writing-intensive courses, internships, undergraduate research, and capstone courses and projects [6].

\section{Course Transformation Project}

Experiential learning activities are often excluded from large introductory courses due to class size, which appears to be prohibitive to a pedagogy geared toward active student learning and engagement. Faculty who teach such courses may often focus on coverage and the dissemination of facts, preferring them as their method of instruction the lecture, but the modern classroom and resources available to instructors have given rise to a new approach for teaching and learning. Transforming these types of courses promotes a learning environment in which students are cognitively engaged (i.e., develop critical thinking skills necessary to deep learning) and socially engaged (i.e., develop relationships with faculty and peers). The Course Transformation Project (CTP) at Northern Illinois University is drawing upon both the need to adapt to higher and more diverse enrollments and the advances in knowledge of learning and digital tools. The CTP turns large lecture courses into blended courses that combine large group lecture, media rich interactive online activities, and small group experiential learning. Turner and Carriveau [1] describe the percentage of contact hour ranges for each of these activities as follows.

Large group lectures: 0-35\%

Media-rich interactive online activities: 30-60\%

Small group experiential learning: $30-50 \%$

Achieving such engagement requires a combination of student interactions with the instructor, each other, and technology. The course being reported on in this paper was transformed to follow these guidelines.

\section{The Course}

OMIS 259, "Introduction to Business Information Systems," is a foundation information systems course required of all business students, and it is taught in an auditorium of a large public Midwestern university and usually contains about 300 students. OMIS 259 teaches web pages, Microsoft Excel, and Microsoft Access (see Appendix for complete list of course Goals and Student Learning Outcomes or SLOs) and was originally taught using lectures, exercises (group and individual), quizzes, and tests. Over time, components were added to the course to increase student engagement and learning. These components include clickers ("classroom response systems"), media-rich interactive online materials, web-based operationalization of students helping students, and webbased operationalization of students receiving course credit for attending appropriate college of business events. These components have been a part of the course for several semesters, and the current transformation added student-produced video tutorials to further increase student engagement.

\section{Clickers}

Clickers, also called "student response systems" or "classroom response systems," are devices which allow students to send answers electronically to questions presented by the instructor in real time. In OMIS 259, students are allowed to discuss questions as the deadline timer counts down. A receiver on the instructor's computer accepts the answers and posts the aggregate results for all students to see. Concepts which were misunderstood show up immediately with poor aggregate results. Aggregate results are posted anonymously, but clicker IDs are associated with student answers so students can receive participation credit. Participation counts as $15 \%$ of each student's OMIS 259 grade, and is a student's "clicker percentage", which is the number of in-class clicker questions answered correctly divided by the total number asked. Everyone gets to drop 10\% of all clicker questions asked without penalty, and so students get a 100-point maximum participation grade as follows.

Participation $=100 *$ clicker percentage $=100 *$ [questions correct/( $90 \%$ of questions asked)] Clickers were used in a similar manner in both the "before" and "after" versions of the course being studied in this research. Usage of clickers has shown to be perceived positively by students and to increase engagement [29] and learning [30].

\section{Media-Rich Interactive Online Materials}

If a larger (60 or more) course has any chance to engage the entire enrollment, some sort of media-rich interactive online software is critical. Fortunately, academic publishers have become increasingly aware that the old model of printed text books, with new editions each year to generate revenue, is going away, and a new best source of future revenue is interactive online material. The course studied for this paper used Pearson's MyITLab for Microsoft Office training, and, setup issues aside, it is an amazing piece of software. MyITLab provides video-based tutorials of Microsoft Office functions, with "Hint" and "Show Me" buttons which allow students to work at their own pace and get extra assistance when and if required. Students must complete the tutorials to earn a grade. Additionally, MyITLab provides cases which require Microsoft Office skills to solve, and students complete the cases, upload their solution files, and get them graded, step by step, almost instantly.

As Turner and Carriveau [1] note, "The online environment is best used to

(i) acquire lower level learning to free up time for in-class experiential learning,

(ii) chunk content to overcome working memory limits,

(iii) provide low-stakes assessments, such as quizzes, for practice and confidence building, 
(iv) provide psychomotor experiences such as drag and drop exercises,

(v) provide concrete experiences that are guided and efficient."

MyITLab meets all of these requirements. Many publishers provide similar software in many different academic disciplines. And, like clickers, MyITLab was a part of the course for several semesters.

\section{Web-Based Operationalization of Students Helping Students}

As enumerated in the previous section, student-to-student interaction and help have proven to be valuable to the learning experience in many ways. However, often the students with more knowledge need to be motivated to help the students with less knowledge. Using something like a webbased "Helper" System can create this motivation. The Helper System used in this class is described by Downing and Liu ([31], p. 195): "the method operationalizes students helping each other and receiving credit for it. The method uses a web-based information system and the process works as follows. Mary helps Joe with a difficult course concept. As compensation, Joe logs in to the information system and registers the fact that Mary has helped him. He also gives Mary a "helpfulness" rating and comments on the help he received. Ratings translate into course points (for Mary and others), and students who accumulate enough points received Bronze, Silver, or Gold "Helper Status". Students who reach Gold status get letters of recommendation from the professor upon request. A survey study conducted in classes using this Helper System versus one not using it suggests that such a system can help with the problems of content understanding, need for multiple explanations, and lack of extra assistance. Student performance on individual course assignments also improved when the Helper System was implemented."

The Helper System had also been used in the course in prior semesters.

\section{Web-Based Operationalization of Students Receiving Course Credit for Attending Appropriate College of Business Events}

If students attend speaking events, seminars, or job-fairs, they are awarded a small amount of class participation credit. Students bring event flyers to the instructor for approval to be included in the "Event System." Approved events are displayed in class prior to the event date. Students who attend the event go to the Event System to indicate that they have attended the event. If a sign-up sheet was at the event, they must also sign that, but, given the small amount of credit being given, instructors do no police this carefully. The Event System operates largely on trust, although a student caught gaming the system will receive a failing participation grade for the course. This aspect of the course is an outside-ofclass engagement technique, so not related exclusively to the course. It encourages more college-wide student engagement, by giving course credit for attending college of business-wide events such as speakers, symposiums, and workshops. Often students need to be motivated to do what is in their best interests, and this is a classic case. So the extra course credit serves as motivation to attend these education-enriching events, and this motivation was also used in past semesters.

\section{Student-Produced Video Tutorials}

When OMIS 259 was chosen to be a transformed course, clickers, MyITLab, the Helper System, and the Event System were already in place. What was severely lacking in the course was the small group experiential activities, and after careful consideration, student-produced video tutorials were chosen as the course addition. Joseph Joubert said "to teach is to learn twice." Much research has shown that teaching a topic is an excellent way to really learn that topic (see, e.g., [32]) and that students taking leadership or consultancy roles in projects increase their interest and engagement [33]. Cortese [34] has shown that teaching a topic is engaging for and leads to enhanced learning for the teacher. The videos in YouTube, Khan Academy, and MOOCs have proven to be efficient methods of delivering content [8]. So students producing and teaching a topic in a video would be engaging for them, and their content could be efficiently delivered to both peers and the instructor. The videos had the additional benefit of having the final product be helpful to their classmates. Instructorassigned groups of 5 students were assigned to explain and demonstrate skills associated with specific Student Learning Outcomes (see Appendix for complete list of course Goals and SLOs) in an online video. All students were given access to the completed online videos through a consolidation page on the course web site, and given that assignments and quizzes covered the skills presented, there was motivation to view the student-created videos. Each student was required to speak on the video and the video could be no more than five minutes long. There are many ways to produce computerscreen-tutorial videos, and students were free to use whatever software they wanted, but for this course we made the free version of Jing from http://techsmith.com/ available on lab computers.

With the addition of the student-produced video tutorials, the percentage of contact hours for Turner and Carriveau's recommended class activities for OMIS 259 became as shown in Table 1.

\section{The Study}

The goal of this study was to compare the "transformed" course, the Fall 2013 course, with the addition of the studentproduced video tutorials, to the course lacking that component (in this case Spring 2013), on student engagement. The goal of this research was certainly not to create and validate a new instrument, so questions from the widely accepted National Survey of Student Engagement (NSSE http://nsse.iub.edu/index.cfm) were used. Table 2 lists the ten questions used for this study. The data analysis plan was to compare responses to these questions over two different semesters, one using student video tutorials and one not, and analyze the mean responses using $z$-testing (two samples 
TABLE 1: OMIS 259 percentage of contact hours for Turner and Carriveau's [1] recommended class activities.

\begin{tabular}{|c|c|c|}
\hline $\begin{array}{l}\text { Online activities (recommended } 30 \% \\
\text { to } 60 \% \text { ) }\end{array}$ & $\begin{array}{l}\text { Large group lecture/face-to-face } \\
\text { (recommended } 0 \% \text { to 35\%) }\end{array}$ & $\begin{array}{l}\text { Small group experiential activities } \\
\text { (recommended } 30 \% \text { to } 50 \% \text { ) }\end{array}$ \\
\hline $\begin{array}{l}\text { Media-Rich Interactive Online } \\
\text { Materials ( } 40 \% \text { ). Students will } \\
\text { complete two individual online } \\
\text { interactive training exercises (graded) } \\
\text { on each of the specific SLO topics. } \\
\text { Students will complete two individual } \\
\text { software exercises (graded) on each of } \\
\text { the specific SLO topics. Software used } \\
\text { will be MyITLab from Pearson. }\end{array}$ & $\begin{array}{l}\text { Lecture (30\%). Answer questions } \\
\text { concerning the business context and } \\
\text { the business uses of SLO topics. } \\
\text { Measured using in-class audience } \\
\text { response system. } \\
\text { Students will spend } 1 \text { hour per week, } \\
\text { on average, listening to lecture. } \\
\text { However, each time a clicker question } \\
\text { is asked (usually about } 10 \text { times per } \\
\text { lecture), students are allowed to } \\
\text { discuss the question and its possible } \\
\text { answers with those around them for } \\
\text { up to } 30 \text { seconds. So, extensive } \\
\text { student-student interaction will take } \\
\text { place even during lecture. }\end{array}$ & $\begin{array}{l}\text { Small Group Experiential Learning } \\
\text { (30\%). Students will complete two } \\
\text { group videos (graded) expanding and } \\
\text { clarifying one specific SLO topic. } \\
\text { Students will complete three group } \\
\text { cases (graded) on aggregated SLO } \\
\text { topics. } \\
\text { There will be approximately } 70 \text { groups } \\
\text { of } 5 \text { students each (course is capped at } \\
350 \text { student enrollment). }\end{array}$ \\
\hline
\end{tabular}

for difference of means). The questions were administered during a normal class period during each of the two semesters being studied. Extra credit was given for completing the survey questions which were asked using clickers. Students were informed that all responses were anonymous, participation was voluntary, and all collected results would be reported in aggregate only. Numbers of responses varied by one or a couple of students per question (students might leave to use the restroom or various other reasons to not answer one or more questions), and 180 students out of the 235 enrolled in OMIS 259 for Spring semester 2013 responded to the survey (76\% response rate) and 250 students out of the 301 enrolled in OMIS 259 for Fall semester 2013 responded to the survey ( $83 \%$ response rate). Of these 430 students who participated in the study, approximately half were male and half were female, and approximately $90 \%$ were Juniors and 10\% were Seniors, with the mean age being 20.1. All students were enrolled in the College of Business.

\section{Results}

The ten questions asked, along with the student response means for each semester to each question, are shown in Table 2. As done in NSSE, response choices were "Very often, Often, Sometimes, and Never," with answers being coded "1" through " 4 ," respectively. Student response means were calculated for both semesters, and $z$-testing (two sample for difference of means) was used with the null hypothesis being that there was no difference in means, and the alternate hypothesis being that the Fall 2013 mean was lower (students were more engaged).

\section{Discussion and Conclusions}

As shown in Table 2, student response means tested as statistically lower for seven out of 10 questions asked. Meaning, students in the Fall 2013 semester, the fully transformed course, responded as being more engaged to $70 \%$ of the questions.
It is worth examining the results for each question individually.

(1) During the Current Semester in OMIS 259, about How Often Have You Felt Like an Engaged Learner. This question was used as an overriding control question, to ask the students point blank if they felt engaged. Of course it is a very important and desirable result that the students indicated a stronger feeling of engagement in the fully transformed Fall 2013 course $(M=1.977)$ than did the students in the Spring 2013 course $(M=2.298)$. A strong $P$ value $(0.000$ to three digits) gives extra credence to this result. Averaging just slightly over "Sometimes" for Spring is still a good result from an absolute standpoint, and given the course components already in place for Spring this is a nice result to have. But comparing that to the 1.977 for Fall 2013 certainly suggests that the addition of the student-produced video tutorials is responsible for the stronger feeling of engagement.

(2) During the Current Semester in OMIS 259, about How Often Have You Done the Following? Asked Questions or Contributed to Course Discussions in Other Ways. This is the first of three questions for which the means of the Spring 2013 course and the transformed Fall 2013 course were statistically equal. The wording of the question offers a possible explanation: students likely associate "asking questions and contributing to course discussions" with the lecture portion of the course. Since that portion of the course did not change from Spring to Fall, it makes sense that the means would be equal for this question.

(3) During the Current Semester in OMIS 259, about How Often Have You Done the Following? Asked Another Student to Help You Understand Course Material. The Spring course had the Helper System in place, yet anecdotally students did not ask each other for help nearly enough without some sort of formal course requirement to get them started in this behavior. Additionally, MyITLab, as a computer tutorial, can be a fairly solitary activity. The addition of the student-produced 
TABLE 2: Engagement question response means, their differences, $P$ values for statistical significance of differences and resulting conclusions.

\begin{tabular}{|c|c|c|c|c|c|c|c|c|}
\hline $\begin{array}{l}\text { Question } \\
\text { number }\end{array}$ & Question & $\begin{array}{c}\text { Spring } 2013 \\
\text { mean }\end{array}$ & $\begin{array}{l}\text { Spring } 2013 \\
\text { standard } \\
\text { deviation }\end{array}$ & $\begin{array}{c}\text { Fall } 2013 \\
\text { mean }\end{array}$ & $\begin{array}{l}\text { Fall } 2013 \\
\text { standard } \\
\text { deviation }\end{array}$ & $\begin{array}{l}\text { Difference } \\
\text { of means }\end{array}$ & $P$ value & Conclusion \\
\hline 1 & $\begin{array}{l}\text { During the current semester in } \\
\text { OMIS } 259, \text { about how often } \\
\text { have you ["initial question } \\
\text { block"], felt like an engaged } \\
\text { learner? }\end{array}$ & 2.298 & 0.800 & 1.977 & 0.786 & 0.321 & 0.000 & $\begin{array}{l}\text { Lower } \\
\text { mean for } \\
\text { fall } 2013 \text {, } \\
\text { more } \\
\text { engaged }\end{array}$ \\
\hline 2 & $\begin{array}{l}\text {...[initial question block], asked } \\
\text { questions or contributed to } \\
\text { course discussions in other ways? }\end{array}$ & 2.994 & 0.952 & 3.136 & 0.904 & -0.141 & 0.059 & $\begin{array}{l}\text { No } \\
\text { difference } \\
\text { in means }\end{array}$ \\
\hline 3 & $\begin{array}{l}\text {...[initial question block], asked } \\
\text { another student to help you } \\
\text { understand course material? }\end{array}$ & 2.807 & 0.984 & 2.596 & 0.964 & 0.210 & 0.013 & $\begin{array}{l}\text { Lower } \\
\text { mean for } \\
\text { fall 2013, } \\
\text { more } \\
\text { engaged }\end{array}$ \\
\hline 4 & $\begin{array}{l}\text {.. [initial question block], } \\
\text { explained course material to one } \\
\text { or more students? }\end{array}$ & 2.626 & 1.016 & 2.434 & 0.924 & 0.192 & 0.022 & $\begin{array}{l}\text { Lower } \\
\text { mean for } \\
\text { fall } 2013 \text {, } \\
\text { more } \\
\text { engaged }\end{array}$ \\
\hline 5 & $\begin{array}{l}\text {...[initial question block], } \\
\text { learned something that changed } \\
\text { the way you understand an issue } \\
\text { or concept? }\end{array}$ & 2.265 & 0.834 & 2.161 & 0.840 & 0.104 & 0.099 & $\begin{array}{l}\text { No } \\
\text { difference } \\
\text { in means }\end{array}$ \\
\hline 6 & $\begin{array}{l}\text { [initial question block], } \\
\text { connected ideas from your } \\
\text { courses to your prior experiences } \\
\text { and knowledge? }\end{array}$ & 2.561 & 0.904 & 2.337 & 0.881 & 0.224 & 0.005 & $\begin{array}{l}\text { Lower } \\
\text { mean for } \\
\text { fall 2013, } \\
\text { more } \\
\text { engaged }\end{array}$ \\
\hline 7 & $\begin{array}{l}\text { During the current semester in } \\
\text { OMIS 259, how much has your } \\
\text { coursework emphasized the } \\
\text { following? [initial question } \\
\text { block2] } \\
\text { memorizing course material }\end{array}$ & 2.117 & 0.876 & 2.117 & 0.882 & 0.000 & 0.499 & $\begin{array}{l}\text { No } \\
\text { difference } \\
\text { in means }\end{array}$ \\
\hline 8 & $\begin{array}{l}\text { [initial question block2] } \\
\text { applying facts, theories, or } \\
\text { methods to practical problems or } \\
\text { new situations? }\end{array}$ & 2.419 & 0.886 & 2.195 & 0.882 & 0.224 & 0.005 & $\begin{array}{l}\text { Lower } \\
\text { mean for } \\
\text { fall } 2013 \text {, } \\
\text { more } \\
\text { engaged }\end{array}$ \\
\hline 9 & $\begin{array}{l}\text { During the current semester in } \\
\text { OMIS 259, to what extent have } \\
\text { your instructors done the } \\
\text { following? } \\
\text { Used examples or illustrations to } \\
\text { explain difficult points }\end{array}$ & 1.797 & 0.835 & 1.525 & 0.718 & 0.271 & 0.000 & $\begin{array}{l}\text { Lower } \\
\text { mean for } \\
\text { fall } 2013 \text {, } \\
\text { more } \\
\text { engaged }\end{array}$ \\
\hline 10 & $\begin{array}{l}\text {...[initial question block], Used } \\
\text { numerical information to } \\
\text { examine a real-world problem or } \\
\text { issue (unemployment, climate } \\
\text { change, public health, etc.) }\end{array}$ & 2.765 & 0.900 & 2.533 & 1.043 & 0.233 & 0.006 & $\begin{array}{l}\text { Lower } \\
\text { mean for } \\
\text { fall 2013, } \\
\text { more } \\
\text { engaged }\end{array}$ \\
\hline
\end{tabular}


video tutorials for Fall 2013 could be a reason this result is significant, at $P=0.013$.

(4) During the Current Semester in OMIS 259, about How Often Have You Done the Following? Explained Course Material to One or More Students. Similar to Question 3, "explaining course material to one or more students" is exactly the type of behavior that the addition of the student-produced video tutorials was designed to increase. While such behavior has been happening during the discussion portion of the clicker questions for many semesters, the fact that the Fall 2013 mean (2.434) was statistically lower than the Spring 2013 mean (2.626), and students felt that they explained course material to one or more students more often in the Fall semester, is encouraging.

(5) During the Current Semester in OMIS 259, about How Often Have You Done the Following? Learned Something That Changed the Way You Understand an Issue or Concept. This is the second (of three) questions where the two semester means showed no statistical difference. While it might be reasonable to assume that students might "learn something that changed the way they understand an issue or concept" while producing or viewing the videos, that did not come across in the results for this question.

(6) During the Current Semester in OMIS 259, about How Often Have You Done the Following? Connected Ideas from Your Courses to Your Prior Experiences and Knowledge. The fact that the Fall mean was lower than the Spring mean at a statistically significant $P=0.005$ for this question is promising. If the videos, or any part of the course, help student connect course ideas to their own (and their peers!) experiences and knowledge that will lead to a better learning experience.

(7) During the Current Semester in OMIS 259, How Much Has Your Coursework Emphasized the Following? Memorizing Course Material. This is the third and final question for which the Spring and Fall means showed no statistical difference. And given that the main transformation was the addition of the student-produced video tutorials, this result is not surprising. There was little memorizing of course material needed for the video assignments, and any memorizing needed to succeed in the course was equally present in Spring and Fall.

(8) During the Current Semester in OMIS 259, How Much Has Your Coursework Emphasized the Following? Applying Facts, Theories, or Methods to Practical Problems or New Situations. The production of the student-produced video tutorials could undoubtedly be considered a "practical problem or new situation," and the fact that the Fall 2013 students felt they applied facts, theories, and methods to such problems/situations more so than the Spring 2013 students is a nice result.

(9) During the Current Semester in OMIS 259, to What Extent Have Your Instructors Done the Following? Used Examples or Illustrations to Explain Difficult Points. Fall 2013 students again felt this happened at a more frequent level than did Spring 2013 students. This result is interesting and unexpected in that the instructor was not the one who produced the video tutorials. However, given that the instructor provided the consolidated page of all student-produced videos on the course web site, it is possible that students saw this as the instructor using examples to explain difficult points.

(10) During the Current Semester in OMIS 259, about How Often Have You Done the Following? Used Numerical Information to Examine a Real-World Problem or Issue (Unemployment, Climate Change, Public Health, etc.). Once again Fall students reported having a higher incidence for this question than Spring students. As many of the SLO skill examples required to be covered in the video tutorials were case-based spreadsheet or database exercises, it is possible that students saw those assignments as increasing their opportunity to use numerical information to examine real-world problems.

(11) During the Current Semester in OMIS 259, about How Often Have You Felt That the Skill Video Assignments Have Increased Your Engagement? This question was not asked in Spring 2013, as the video assignment was not included in that course nor was the result reported in Table 2. For Fall 2013 the mean for this question was a very strong 2.13 , suggesting that the addition of the student-produced video tutorials added to the feeling of engagement in the course.

Taken in their entirety, the results suggest that student engagement is increasing in OMIS 259. The addition of the student-produced video tutorials is one reason for this increase. As these assignments are tweaked and expanded and as the balance and content of the online activities, large group lecture, and small group experiential activities are adjusted and perfected, it is expected that student engagement will continue to rise.

While the results are encouraging, it is important to note that the student population was not the same from semester to semester. While every effort was made to control the two environments being compared, it is impossible to control the student population. It is conceivable that the Fall 2013 class was stocked with more engaged and better students in general, and larger and better experimental design is needed before conclusions can be generalizable. Additional and more sophisticated comparison of students and classes over time can address this limitation.

\section{Appendix}

\section{Course Assessment, Goals, and Student Learning Outcomes}

OMIS 259: Introduction to Business Information Systems (transformed)

Final Assessment Plan

Including GLOs, SLOs, Assignments and Measurement 
Goal. Select appropriate technology tool to satisfy the needs of a business context.

General Learning Outcomes (3)

GLO 1. Select appropriate Excel tool to satisfy the needs of a business context.

Student Learning Outcomes (6)

(SLO 1) Independently and outside of class, given a business case, create and complete an Excel spreadsheet, which utilizes workbook management techniques, formatting, page setup, and printing, to meet the specifications of the case with at least a $70 \%$ level of correctness.

(SLO 2) Independently and outside of class, given a business case, create and complete an Excel spreadsheet, which utilizes formulas and functions, to meet the specifications of the case with at least a $70 \%$ level of correctness.

(SLO 3) Independently and outside of class, given a business case, create and complete an Excel spreadsheet, which utilizes charts, to meet the specifications of the case with at least a $70 \%$ level of correctness.

(SLO 4) Independently and outside of class, given a business case, create and complete an Excel spreadsheet, which utilizes datasets and tables, to meet the specifications of the case with at least a $70 \%$ level of correctness.

(SLO 5) Independently and outside of class, given a business case, create and complete an Excel spreadsheet, which utilizes subtotals, PivotTables and PivotCharts, to meet the specifications of the case with at least a $70 \%$ level of correctness.

(SLO 6) Independently and outside of class, given a business case, create and complete an Excel spreadsheet, which utilizes What-If analysis, to meet the specifications of the case with at least a $70 \%$ level of correctness.

\section{Assignments and Measurement}

Lecture (30\%). Answer questions concerning the business context and the business uses of SLO topics. Measured using in-class audience response system.

Media-Rich Interactive Online Materials (40\%). Complete two individual online interactive training exercises (graded) on each of the specific SLO topics. Complete two individual software exercises (graded) on each of the specific SLO topics.

Small Group Experiential Learning (30\%). Complete group video (graded) expanding and clarifying one specific SLO. Complete two group cases (graded) on aggregated SLO topics.

Additional Cumulative Measurement. Complete paper quiz on aggregated SLO topics on completion of SLO
Unit(s). Complete paper Final Exam on aggregated course topics.

GLO 2. Select appropriate Access tool to satisfy the needs of a business context.

\section{Student Learning Outcomes (4)}

(SLO 1) Independently and outside of class, given a business case, create and complete an Access database, with tables with formats, keys, data types and relationships, to meet the specifications of the case with at least a $70 \%$ level of correctness.

(SLO 2) Independently and outside of class, given a business case and Access database, create and complete an Access query, to meet the specifications of the case with at least a $70 \%$ level of correctness.

(SLO 3) Independently and outside of class, given a business case and Access database, create and complete an advanced Access query utilizing Expression Builder, to meet the specifications of the case with at least a $70 \%$ level of correctness.

(SLO 4) Independently and outside of class, given a business case and Access database, create and complete professional forms and reports, to meet the specifications of the case with at least a $70 \%$ level of correctness.

\section{Assignments and Measurement}

Lecture (30\%). Answer questions concerning the business context and the business uses of SLO topics. Measured using in-class audience response system.

Media-Rich Interactive Online Materials (40\%). Complete two individual online interactive training exercises (graded) on each of the specific SLO topics. Complete two individual software exercises (graded) on each of the specific SLO topics.

Small Group Experiential Learning (30\%). Complete group video (graded) expanding and clarifying one specific SLO. Complete one group case (graded) on aggregated SLO topics.

Additional Cumulative Measurement. Complete paper quiz on aggregated SLO topics on completion of SLO Unit(s). Complete paper Final Exam on aggregated course topics.

GLO 3. Select appropriate Web tool to satisfy the needs of a business context.

\section{Student Learning Outcomes (3)}

(SLO 1) Independently and outside of class, create a simple web page using html displaying student name and picture with at least a $70 \%$ level of correctness.

(SLO 2) Independently and outside of class, create a simple resume as a web page using MS Word with at least a $70 \%$ level of correctness. 
(SLO 3) Independently and outside of class, FTP the web page and resume to the student web server space so that anyone with an Internet connection and browser can see it from anywhere in the world, with at least a $70 \%$ level of correctness.

\section{Assignments and Measurement}

Lecture (30\%). Answer questions concerning the business context and the business uses of SLO topics. Measured using in-class audience response system.

Media-Rich Interactive Online Materials (40\%). Complete one individual online software exercise (graded) on aggregated SLO topics.

Small Group Experiential Learning (30\%). Complete group video (graded) expanding and clarifying one specific SLO.

Additional Cumulative Measurement. Complete paper quiz on aggregated SLO topics on completion of SLO Unit(s). Complete paper Final Exam on aggregated course topics.

\section{Conflict of Interests}

The authors declare that there is no conflict of interests regarding the publication of this paper.

\section{References}

[1] P. Turner and R. Carriveau, Next Generation Course Redesign, Peter Lang, 2010.

[2] C. Wieman, "Why not try a scientific approach to science education?" Change: The Magazine of Higher Learning, vol. 39, no. 5, pp. 9-15, 2007.

[3] E. F. Barkley, Student Engagement Techniques: A Handbook for College Faculty, John Wiley \& Sons, 2009.

[4] D. W. Harward and A. P. Finley, Eds., Transforming Undergraduate Education: Theory That Compels and Practices That Succeed, Rowman \& Littlefield, 2012.

[5] Hart Research Associates, "It takes more than a major: employer priorities for college learning and student success," AAC\&U, 2013.

[6] Association of American Colleges and Universities, The LEAP Vision for Learning: Outcomes, Practices, Impact and Employer's Views, Association of American Colleges and Universities, 2011.

[7] S. L. Newstok, "A plea for 'Close Learning", Liberal Education, vol. 99, no. 4, 2013.

[8] F. G. Martin, "Education will massive open online courses change how we teach," Communications of the ACM, vol. 55, no. 8, pp. 26-28, 2012.

[9] Y. Hill, L. Lomas, and J. MacGregor, "Students' perceptions of quality in higher education," Quality Assurance in Education, vol. 11, no. 1, pp. 15-20, 2003.

[10] J. E. Zull, The Art of Changing the Brain: Enriching Teaching by Exploring the Biology of Learning, Stylus Publishing, 2002.

[11] S. A. Ambrose, M. W. Bridges, M. DiPietro, M. C. Lovett, and M. K. Norman, How Learning Works: Seven Research-Based Principles for Smart Teaching, John Wiley \& Sons, 2010.
[12] K. Taylor and D. Rohrer, "The effects of interleaved practice," Applied Cognitive Psychology, vol. 24, no. 6, pp. 837-848, 2010.

[13] J. Metcalfe and N. Kornell, "A region of proximal Learning model of study time allocation," Journal of Memory and Language, vol. 52, no. 4, pp. 463-477, 2005.

[14] M. K. Tallent-Runnels, J. A. Thomas, W. Y. Lan et al., “Teaching courses online: a review of the research," Review of Educational Research, vol. 76, no. 1, pp. 93-135, 2006.

[15] S. M. Smith and E. Vela, "Environmental context-dependent memory: a review and meta-analysis," Psychonomic Bulletin and Review, vol. 8, no. 2, pp. 203-220, 2001.

[16] F. Concannon, A. Flynn, and M. Campbell, "What campusbased students think about the quality and benefits of elearning," British Journal of Educational Technology, vol. 36, no. 3, pp. 501-512, 2005.

[17] X. Yang, Y. Li, C.-H. Tan, and H.-H. Teo, "Students' participation intention in an online discussion forum: why is computermediated interaction attractive?" Information and Management, vol. 44, no. 5, pp. 456-466, 2007.

[18] R. D. Roscoe and M. T. H. Chi, “Tutor learning: the role of explaining and responding to questions," Instructional Science, vol. 36, no. 4, pp. 321-350, 2008.

[19] T. D. Griffin, J. Wiley, and K. W. Thiede, "Individual differences, rereading, and self-explanation: concurrent processing and cue validity as constraints on metacomprehension accuracy," Memory and Cognition, vol. 36, no. 1, pp. 93-103, 2008.

[20] C. Bereiter and M. Scardamalia, "Cognitive coping strategies and the problem of "inert" knowledge," in Thinking and Learning Skills: Current Research and Open Questions, vol. 2, pp. 6580, 1985.

[21] R. A. Bjork, Retrieval practice and the maintenance of knowledge, 1998.

[22] R. E. Mayer and R. Moreno, "Nine ways to reduce cognitive load in multimedia learning," Educational Psychologist, vol. 38, no. 1, pp. 43-52, 2003.

[23] J. Larreamendy-Joerns and G. Leinhardt, "Going the distance with online education," Review of Educational Research, vol. 76, no. 4, pp. 567-605, 2006.

[24] J. Herrington, R. Oliver, and T. C. Reeves, "Patterns of engagement in authentic online learning environments," Australian Journal of Educational Technology, vol. 19, no. 1, pp. 59-71, 2003.

[25] S. D. Wurdinger and J. A. Carlson, Teaching for Experiential Learning: Five Approaches That Work, R\&L Education, Lanham, Md, USA, 2009.

[26] M. Miller and M. Y. Lu, "Serving non-traditional students in elearning environments: building successful communities in the virtual campus," Educational Media International, vol. 40, no. 1-2, pp. 163-169, 2003.

[27] G. D. Kuh, T. M. Cruce, R. Shoup, J. Kinzie, and R. M. Gonyea, "Unmasking the effects of student engagement on first-year college grades and persistence," The Journal of Higher Education, vol. 79, no. 5, pp. 540-563, 2008.

[28] L. E. Swaner, "The theories, contexts, and multiple pedagogies of engaged learning: what succeeds and why," in Transforming Undergraduate Education: Theories that Compel and Practices that Succeed, pp. 73-90, Rowman \& Littlefield, Lanham, Md, USA, 2012.

[29] A. R. Trees and M. H. Jackson, "The learning environment in clicker classrooms: student processes of learning and involvement in large university-level courses using student response systems," Learning, Media and Technology, vol. 32, no. 1, pp. 2140, 2007. 
[30] S. A. Yourstone, H. S. Kraye, and G. Albaum, "Classroom questioning with immediate electronic response: do clickers improve learning?" Decision Sciences Journal of Innovative Education, vol. 6, no. 1, pp. 75-88, 2008.

[31] C. Downing and C. Liu, "Getting students to teach each other: doing more with less in IS education," Journal of Information Technology and Application in Education, vol. 1, no. 4, pp. 195206, 2012.

[32] J. Senese, “Teach to Learn," Studying Teacher Education: A Journal of Self-Study of Teacher Education Practices, vol. 1, no. 1, pp. 43-54, 2005.

[33] S. S. Erzurumlu and K. Rollag, "Increasing student interest and engagement with business cases by turning them into consulting exercises," Decision Sciences Journal of Innovative Education, vol. 11, no. 4, pp. 359-381, 2013.

[34] C. G. Cortese, "Learning through teaching," Management Learning, vol. 36, no. 1, pp. 87-115, 2005. 

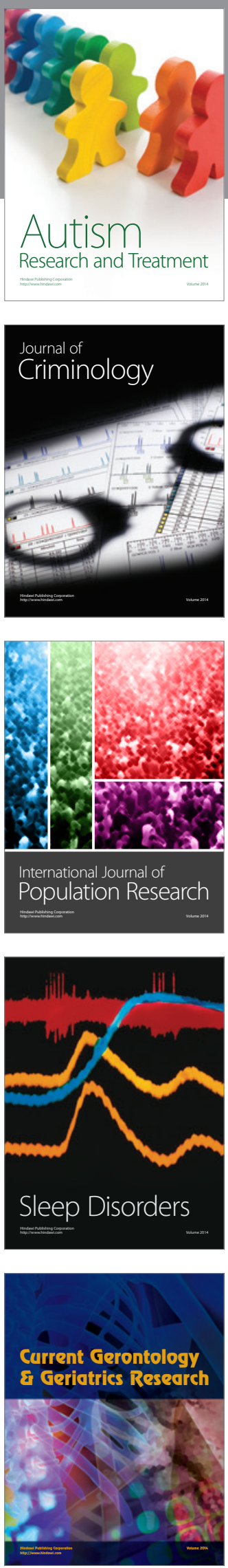
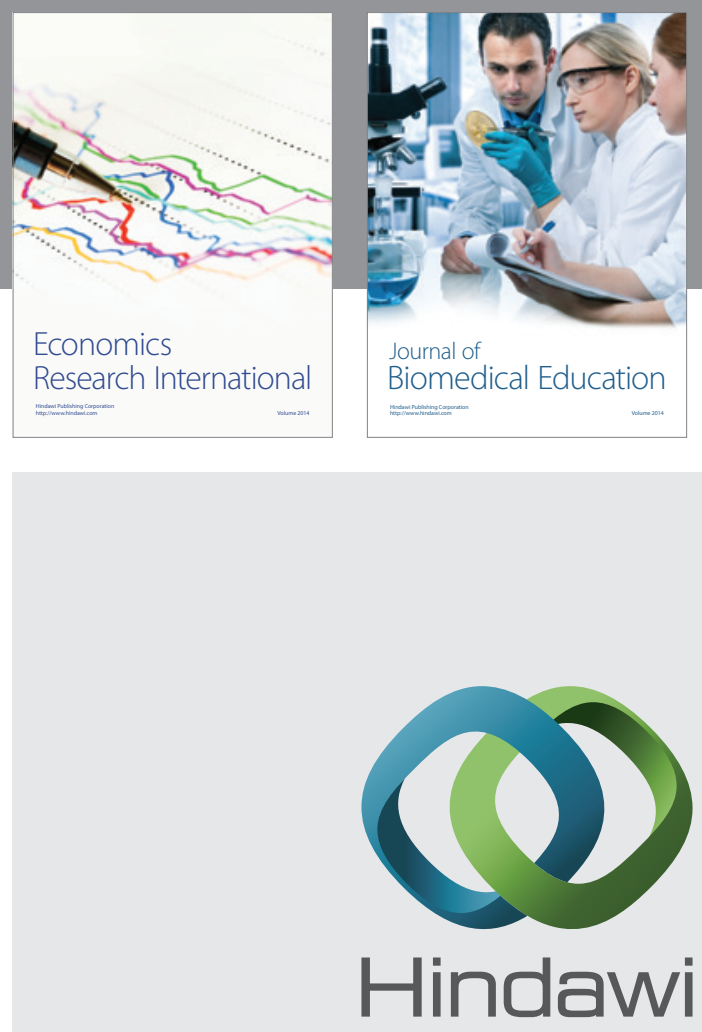

Submit your manuscripts at

http://www.hindawi.com
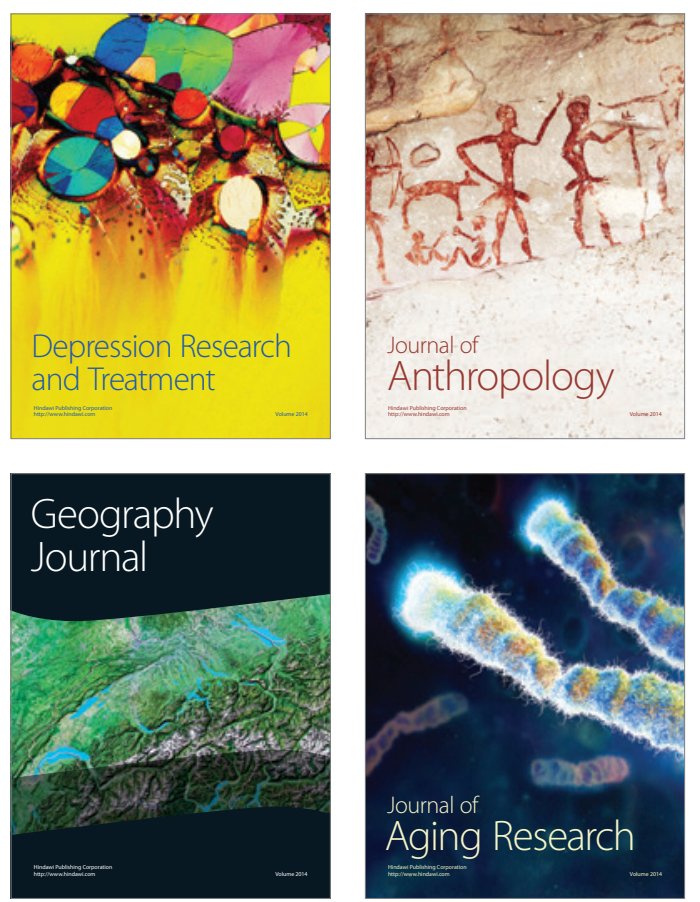
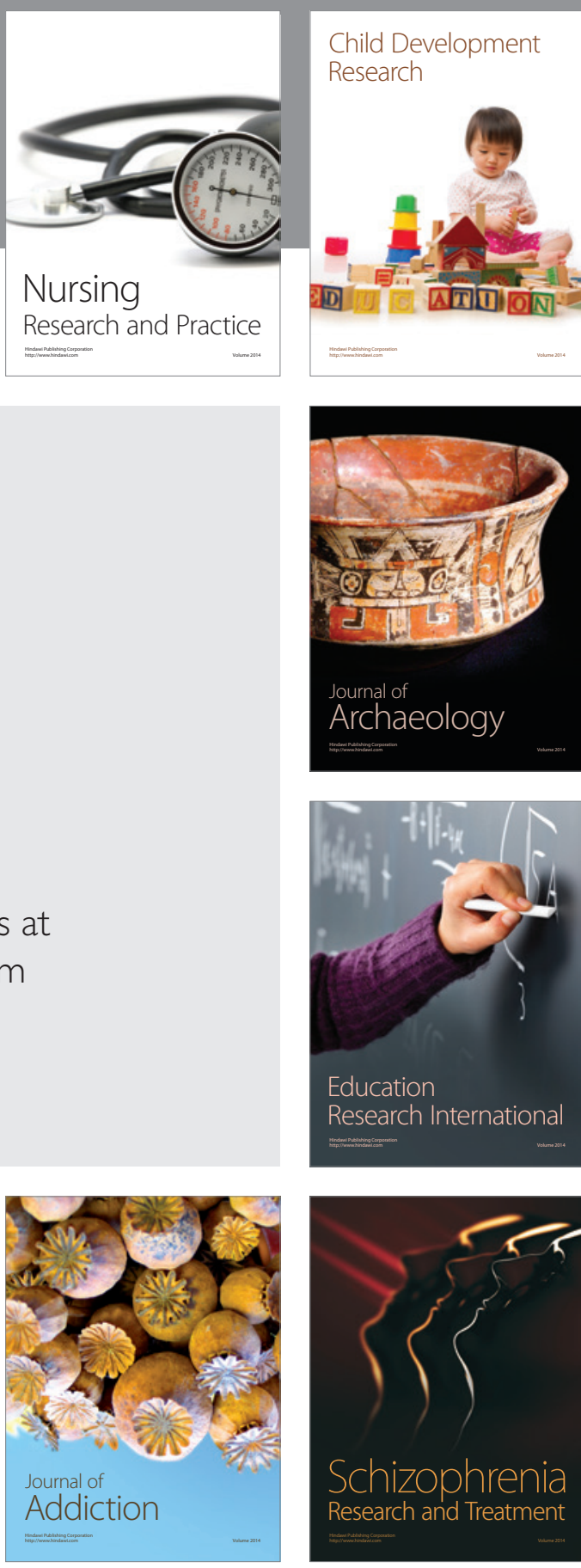

(D)
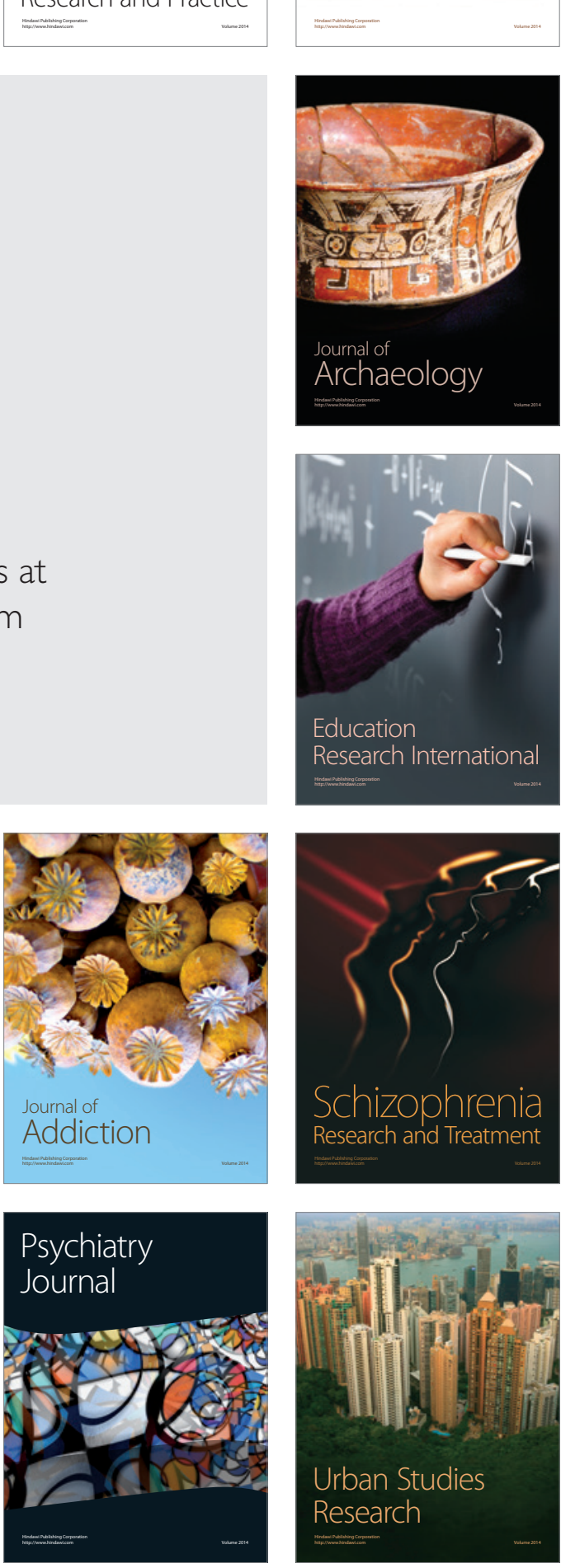